\title{
Analysis of complaints to a tertiary care pain clinic over a nine-year period
}

\author{
Angela Mailis-Gagnon MD MSc FRCPC, Keith Nicholson PhD, Luis Chaparro MD
}

\begin{abstract}
A Mailis-Gagnon, K Nicholson, L Chaparro. Analysis of complaints to a tertiary care pain clinic over a nine-year period. Pain Res Manage 2010;15(1):17-23.
\end{abstract}

BACKGROUND: The present study is the result of an internal audit and examines the profiles of complainants and the sources and nature of complaints toward the staff in a tertiary care pain clinic, the Comprehensive Pain Program of the Toronto Western Hospital in Toronto, Ontario.

METHODS: All sources of complaints over a nine-year period were reviewed, which included the following: Toronto Western Hospital Patient Relations (PR) records, with a subset of the files qualitatively analyzed in depth regarding the nature of complaints and complainants; complaints that bypassed PR and were addressed directly to the program director against members of the staff; complaints to the College of Physicians and Surgeons of Ontario; and complaints recorded anonymously at rateMDs.com.

RESULTS: Although the prevalence of PR complaints was very low ( 1.73 complaints per 1000 visits), several other sources of complaints were identified. The typical complainant was a Canadian-born woman acting on her behalf or on behalf of a family member. More than one-half of the complaints were directed against the physicians regarding their opinion of psychological factors augmenting the patient's presentation and/or inappropriate use of opioids. Defensive techniques instituted by the Comprehensive Pain Program staff in reaction to the complaints are discussed, and pertinent literature is reviewed.

CONCLUSION: The present study is the first to examine the nature of complaints and complainants from a Canadian pain clinic. Further studies are needed to explore the complex issues of patient and staff interactions, and complaints in the era of 'patient-centred care'.

Key Words: Chronic pain; Complaints; Pain clinic

\section{Analyse des plaintes à l'endroit d'une clinique de la douleur en soins tertiaires au cours d'une période de neuf ans}

\begin{abstract}
HISTORIQUE : La présente étude est le résultat d'une vérification interne; elle examine le profil des personnes ayant porté plainte, de même que la source et la nature des plaintes formulées à l'endroit du personnel d'une clinique de la douleur en soins tertiaires, le Comprehensive Pain Program du Toronto Western Hospital de Toronto, en Ontario.

MÉTHODES : Toutes les sources des plaintes formulées sur une période de neuf ans ont été passées en revue. Elles incluaient : les dossiers des relations avec les patients du Toronto Western Hospital et une série de dossiers analysés en profondeur en ce qui a trait à la nature des plaintes et des personnes ayant porté plainte, les plaintes à l'endroit de membres du personnel adressées directement au directeur du programme (sans passer par les relations avec les patients), les plaintes adressées au Collège des médecins et chirurgiens de l'Ontario et les plaintes formulées de façon anonyme à l'adresse rateMDs.com.

RÉSULTATS : Bien que la prévalence des plaintes adressées aux relations avec les patients ait été très faible (1,73 plainte par 1000 consultations), plusieurs autres sources de plaintes ont été identifiées. La personne portant plainte était typiquement une femme née au Canada et agissant en son propre nom ou au nom d'un proche. Plus de la moitié des plaintes étaient dirigées contre des médecins et avaient trait à leur perception des facteurs psychologiques ayant pu exacerber le tableau douloureux et/ou à l'emploi inapproprié des opiacés. On aborde ici les techniques défensives adoptées par le personnel du Comprehensive Pain Program au sujet des plaintes et on passe en revue la littérature pertinente.

CONCLUSION : La présente étude est la première à examiner la nature des plaintes et le profil des personnes qui ont porté plainte dans une clinique de la douleur au Canada. Il faudra procéder à d'autres études pour explorer les interactions complexes entre les patients et le personnel et les plaintes dans le domaine des soins axés sur les patients.
\end{abstract}

If one can conceptualize patient care as a pyramid, at the apex is the highest level of patient-centred, collaborative care and at the base are measures of 'what is the matter' (from the clinical perspective) and 'what matters' (from the patient perspective) (2). In this climate, in which staff must focus on listening and communicating with patients and their families, organizations and institutions have an interest in collecting satisfaction data from patients to improve delivery of care. Complaint analysis helps to highlight service gaps, and procedures and policies that need to be changed. Although such analysis is reflected in a growing body of literature in the business and marketing world regarding dissatisfaction, complaining and handling of complaints, it is a relatively unusual topic in the medical literature. In the medical field, a complaint is often considered a source of shame, is kept secret or safety, and cultural diversity".

Comprehensive Pain Program, Toronto Western Hospital, University Health Network and University of Toronto Centre for the Study of Pain, Toronto, Ontario

Correspondence: Dr Angela Mailis-Gagnon, Toronto Western Hospital, Krembil Neuroscience Centre and Toronto Western Research Institute, Department of Medicine, University of Toronto, Toronto Western Hospital, Toronto, Ontario M5T 2S8. Telephone 416-603-5380,

fax 416-603-5725, e-mail angela.mailis@uhn.on.ca 
TABLE 1

\section{Summary of complaints filed with Toronto Western Hospital Patient Relations (Toronto, Ontario; January 1, 1999, to January 1, 2008)}

\begin{tabular}{lcc}
\hline Complaint against & Female complainant & Male complainant \\
\hline CPP director & 8 & - \\
Other physician & - & 2 \\
Administrative staff & 7 & 3 \\
General & 3 & - \\
Total $(\mathrm{n}=23)$ & 18 & 5 \\
\hline
\end{tabular}

CPP Comprehensive Pain Program

may be reacted to in a defensive style of practice that may actually decrease quality of care.

Published studies (3-5) from different hospital departments and services indicate a highly variable number of complaints ranging from 0.04 to 45.2 per 1000 visits or patients. While there are several studies relating to patients' complaints toward hospital departments, services or emergencies (6-9), there were no retrievable studies published from pain clinics in particular.

Chronic pain patients seen at pain clinics are different from pain patients seen in primary care settings $(10,11)$. These pain clinic patients present with complex pain problems and high levels of psychosocial issues. It is also known that, in general, chronic pain patients consume increased health care services and present with higher levels of pain and psychosocial dysfunction than patients without pain (12). Therefore, it is easy to conceptualize that relationships between such patients and clinic staff are sometimes difficult and may result in complaints being launched by patients. Unlike business settings, meeting patients' expectations does not necessarily result in better health care. Nowhere is this more the case than in a pain clinic, where what people want or think they need may not always be in their best interest.

The present study was initiated as an internal audit to review patient complaints over a nine-year period in a tertiary care pain clinic established in 1982 and affiliated with the University of Toronto (Comprehensive Pain Program [CPP] at Toronto Western Hospital [TWH], Toronto, Ontario). The study examines the sources and nature of complaints and complainants, and discusses the defensive approach of the clinic staff with regard to delivery of services.

\section{METHODS}

All sources of complaints against the CPP medical and administrative staff were collected over a nine-year period from January 1 , 1999, to January 1, 2008. These included the following:

- The TWH Patient Relations (PR) records, which provided the number of complaints, complainant's sex and person(s) against whom the complaint was made. Information was also collected from the PR department with regard to the number of complaints filed against other programs for comparison. A subset of the PR complaints was analyzed qualitatively because the CPP had kept detailed files that contained sex, country of birth and other demographic data as well as details of complaints to PR.

- CPP files containing complaints addressed directly to the program director (bypassing PR).

- Complaints to the College of Physicians and Surgeons of Ontario (CPSO) against the CPP physicians.
- Complaints recorded anonymously against medical staff at rateMDs.com, a public Web site in the United States and Canada.

Approval was obtained from the Research Ethics Board of the institution regarding retrospective review of the files. Permission was also obtained from physicians and administrative staff of the CPP.

\section{RESULTS}

Complaints launched with the PR department

The Krembil Neuroscience Centre at TWH includes all clinical services, education and research generated by 11 separate programs, one of which is the CPP. In the nine-year period reported in the present study (January 1, 1999, to January 1, 2008), the PR office indicated that there were three programs with 20 to 25 registered complaints (neuro-ophthalmology clinic, neurology clinic and CPP), six programs with eight to 14 complaints (neurology, neurosurgery, electromyography laboratory, movement disorders clinic, and sleep and alertness clinic) and two programs with one to two complaints (neuropsychology and sleep laboratory). With regard to the pain program, there were 23 complaints launched against the CPP. The female to male ratio of the complainants was 3.6:1 (18 women and five men). The complaints were spread between medical and administrative staff (Table 1) and represented a period prevalence of $0.17 \%$ (23 per 13,500 visits over a nine-year period) or $0.019 \%$ per year. Alternatively, this corresponds to 2.6 complaints per year or a complaint frequency of $1.73 \mathrm{com}$ plaints per 1000 visits. The PR department indicated only that "the complaints were related in general to care, attitude or communication", with no further details. Because there was no access to PR and other data regarding details of complaints against other programs (reasons, sex, or information related to the person against whom the complaints were launched, or the number of patient visits per program yearly), comparisons cannot be made between CPP and other programs with regard to the frequency or prevalence, nature, or the profile of complainants.

Qualitative analysis of complaints: A detailed qualitative analysis of 13 of the 23 CPP files for patients who launched complaints with PR during the nine-year period in question was possible because some, but not all, of the patients' letters were kept in the authors' files. The analysis permitted sex and country of birth identification of the complainants, recognition of the details and nature of specific complaints, and type of resolution (Table 2). All 13 qualitatively analyzed complaints in the files were launched by women. More than onehalf of the complaints (eight of 13) were against the medical staff, with the complainants disliking the diagnosis and recommendations or approach. Actually, such complaints nearly always related to the physicians who were commenting in their consultation note on psychological factors augmenting patients' pain perception and contributing to their disability, and recommending that the prescribed opioids should either be tapered or discontinued when the patients were on large doses in the absence of significant pathology and pain relief. In one case, the complainant disliked the consultant's approach but felt confident about the diagnosis (patient 9, Table 2). The remaining five of 13 complaints related to patient interactions with the administrative staff, in particular with the female 
TABLE 2

Qualitative analysis of complaints filed with Toronto Western Hospital Patient Relations (PR) (Toronto, Ontario)

\begin{tabular}{|c|c|c|c|c|}
\hline Year & Patient & $\begin{array}{l}\text { Complainant sexl } \\
\text { country of birth }\end{array}$ & Substance of complaint & Resolution \\
\hline 1999 & 1 & $\mathrm{~F} / \mathrm{CB}$ & $\begin{array}{l}\text { Upset when bed was cancelled by administrative } \\
\text { staff (due to bed emergency in the hospital) }\end{array}$ & $\begin{array}{l}\text { New admission date given but patient failed to show, being out of } \\
\text { town without giving notice* }\end{array}$ \\
\hline 1999 & 2 & $\mathrm{~F} / \mathrm{CB}$ & Alleged administrative staff unhelpful and uncaring & $\begin{array}{l}\text { Staff found accusations unfounded because patient had serious } \\
\text { psychiatric history* }\end{array}$ \\
\hline 1999 & 3 & $\mathrm{~F} / \mathrm{CB}$ & $\begin{array}{l}\text { Asked PR not to reveal complaint regarding } \\
\text { administrative staff until after admission; she found } \\
\text { admission to be very helpful }\end{array}$ & $\begin{array}{l}\text { Staff discussed complaint with patient at follow-up. Patient } \\
\text { apologized, admitted she was under stress and retracted } \\
\text { complaint* }^{*}\end{array}$ \\
\hline 1999 & 4 & F/Unknown & $\begin{array}{l}\text { Disliked physician's recommendations regarding } \\
\text { decrease of opioids }\end{array}$ & PR advised that patient is obliged to abide by program's policies \\
\hline 2000 & 5 & $\mathrm{~F} / \mathrm{CB}$ & $\begin{array}{l}\text { Disliked physician's diagnosis, demanded withdrawal } \\
\text { of diagnosis and change in consultant's opinion }\end{array}$ & $\begin{array}{l}\text { PR mediated lengthy meeting between physician and patient. } \\
\text { Patient very angry and unsettled, threatened PR and physician. } \\
\text { PR filed a detailed letter regarding encounter for future reference* }\end{array}$ \\
\hline 2001 & 6 & $\mathrm{~F} / \mathrm{CB}$ & Disliked physician's comment on consultation note & $\begin{array}{l}\text { Patient misunderstood medical terminology, explanatory letter } \\
\text { written }\end{array}$ \\
\hline 2003 & 7 & $\mathrm{~F} / \mathrm{CB}$ & Disliked administrative staff's responses & $\begin{array}{l}\text { When CPP director mediated, patient apologized, altered } \\
\text { complaint* }^{*}\end{array}$ \\
\hline 2003 & 8 & $\mathrm{~F} / \mathrm{CB}$ & $\begin{array}{l}\text { Disliked physician's description of patient's } \\
\text { appearance and demeanour in consultation note }\end{array}$ & $\begin{array}{l}\text { Physician responded in writing by explaining why observations on } \\
\text { appearance, demeanour and behaviour are important in a pain } \\
\text { consultation }\end{array}$ \\
\hline 2004 & 9 & $\begin{array}{l}\mathrm{F} \text { (mother of } \\
\text { patient)/CB }\end{array}$ & $\begin{array}{l}\text { Very happy with physician's care and management, } \\
\text { but believed physician could be more sensitive to } \\
\text { daughter's feelings }\end{array}$ & $\begin{array}{l}\text { PR advised mother to discuss this with physician. Mother never } \\
\text { pursued further communication }\end{array}$ \\
\hline 2004 & 10 & F/CB & $\begin{array}{l}\text { Complained of not being given an appointment by } \\
\text { administrative staff after referral }\end{array}$ & $\begin{array}{l}\text { CPP staff confirmed several telephone calls to the correct number/ } \\
\text { address but no answer/reply* }\end{array}$ \\
\hline 2006 & 11 & $\begin{array}{l}\mathrm{F} \text { (partner of } \\
\text { patient)/CB }\end{array}$ & $\begin{array}{l}\text { Complained calls were not returned within } 3 \mathrm{~h} \text { and } \\
\text { that administrative staff was insensitive and rude }\end{array}$ & $\begin{array}{l}\text { Complainant was advised that staff was busy with clinic, and calls } \\
\text { would be returned after clinic. Partner and patient later } \\
\text { apologized* }\end{array}$ \\
\hline 2006 & 12 & $\begin{array}{l}\mathrm{F} \text { (partner of } \\
\text { patient)/CB }\end{array}$ & $\begin{array}{l}\text { Complained regarding consultation terminology and } \\
\text { 'attire' of physician she found 'unprofessional' }\end{array}$ & $\begin{array}{l}\text { With PR guidance, physician wrote explanatory letter regarding } \\
\text { terminology, stressed that physician is expected to be judged on } \\
\text { knowledge and not attire }\end{array}$ \\
\hline 2007 & 13 & $\mathrm{~F} / \mathrm{CB}$ & $\begin{array}{l}\text { Complained regarding physician's diagnosis and } \\
\text { examination }\end{array}$ & PR advised physician that patient just 'wanted to vent' feelings \\
\hline
\end{tabular}

*Complaint was considered unfounded by medical and administrative staff. CB Canadian born; CPP Comprehensive Pain Program; F Female

secretary of the program. The complaints against the medical staff were resolved in variable ways (clarifications given by the physician or PR, notification of the patient as to the firm position of the physicians or the policies of the program, etc). The complaints against administrative staff were related to issues of communication or misunderstanding and were resolved satisfactorily via PR or by the CPP director communicating with the complainant. In particular, seven of 13 complaints were found to lack merit and three patients later retracted their complaint and apologized to physicians and staff. Details of complainants, nature of complaints and resolution, as well as which complaints were considered unfounded, are shown in Table 2.

\section{Complaints filed directly with the CPP director}

Three additional complaints were brought to the attention of the CPP director in the nine-year period in question (against other medical or administrative staff). Resolution of these complaints was performed via written or verbal communication. These complaints (one each) related to the medical staff consultation note, communication with administrative staff, and the typos and tone of the notification letter regarding the clinic appointment. Details are shown in Table 3.

\section{Complaints filed with the CPSO}

Three complaints specifically against the CPP director (the senior author of the present study, together with other medical or support staff) were filed with the CPSO Complaints Committee. Each complaint included several allegations (eg, not devoting enough time to examination, diagnosis was not proper, staff did not introduce themselves, attitude was condescending, staff was unqualified, informed consent was not obtained, etc). These complaints resulted in elaborate and lengthy reviews by the CPSO in two cases (Table 4). In cases 1 and 2 , it took 2.5 years and eight months, respectively, for the process to be completed and the issue to close. In case 1 , the CPP director sought Canadian Medical Protective Association advice toward the end of the lengthy process, only to be informed that the same complainant had 'a file' with the Canadian Medical Protective Association because he had launched numerous similar complaints against the staff of another hospital, claiming, in addition to other things, that they "sexually assaulted his sister while under anesthesia". In case 1, the CPSO administered a reprimand to the CPP director indicating that informed consent to a patient with a poor command of English should be more elaborate (of note, this resulted in the addition of two more consent forms and 
TABLE 3

Complaints filed directly with the Comprehensive Pain Program (CPP) director

\begin{tabular}{|c|c|c|c|}
\hline Year & $\begin{array}{l}\text { Complainant sexl } \\
\text { country of birth }\end{array}$ & Substance of complaint & Resolution \\
\hline 2000 & $\begin{array}{l}\mathrm{F} \text { (secretary of } \\
\text { other office)/CB }\end{array}$ & Unhappy with administrative staff handling of a referral & CPP director mediated between staff and complainant \\
\hline 2003 & F/CB & $\begin{array}{l}\text { Disliked consultant's note indicating alcohol abuse, requested } \\
\text { alteration of note }\end{array}$ & $\begin{array}{l}\text { CPP director confirmed current alcohol abuse based on } \\
\text { documentation on file and supported staff physician's } \\
\text { position }\end{array}$ \\
\hline 2006 & $\begin{array}{l}M \text { (spouse of } \\
\text { patient)/CB }\end{array}$ & $\begin{array}{l}\text { Complained regarding typo in letter of appointment notification } \\
\text { and letter style he considered 'condescending and arrogant' }\end{array}$ & $\begin{array}{l}\text { CPP director wrote explanation regarding style of letter of } \\
\text { notification }\end{array}$ \\
\hline
\end{tabular}

CB Canadian born; F Female; M Male

TABLE 4

Complaints filed with the College of Physicians and Surgeons of Ontario (CPSO)

\begin{tabular}{|c|c|c|c|}
\hline Year & $\begin{array}{l}\text { Complainant sexl } \\
\text { country of birth }\end{array}$ & Substance of complaint & Resolution \\
\hline 2000 & $\begin{array}{l}\text { M (brother of } \\
\text { patient)/FB }\end{array}$ & $\begin{array}{l}\text { Complainant launched numerous complaints against director } \\
\text { and other medical staff, alleging that his sister was submitted } \\
\text { to procedures without consent, or that the physician 'forged' } \\
\text { signatures on consent }\end{array}$ & $\begin{array}{l}\text { After } 2.5 \text { years of proceedings, CPSO 'reprimanded' director to } \\
\text { make sure patients understand informed consent. Complainant } \\
\text { dropped appeal at the CPSO Tribunal after a further } \\
\text { disconcerting letter to CPSO }\end{array}$ \\
\hline 2007 & $\begin{array}{c}\text { F/FB (came to } \\
\text { Canada at age } 4 \text { ) }\end{array}$ & $\begin{array}{l}\text { Alleged director lacked knowledge and other medical staff were } \\
\text { unqualified and 'flirting' with resident }\end{array}$ & $\begin{array}{l}\text { CPSO closed the case in two months after staff credentials were } \\
\text { verified }\end{array}$ \\
\hline 2007 & $\mathrm{M} / \mathrm{CB}$ & $\begin{array}{l}\text { Numerous complaints against director and other medical staff } \\
\text { regarding behaviour, diagnosis, recommendations, etc }\end{array}$ & $\begin{array}{l}\text { CPSO conducted a very thorough investigation over a period of } \\
\text { eight months and concluded that none of the allegations had } \\
\text { any merit }\end{array}$ \\
\hline
\end{tabular}

CB Canadian born; F Female; FB Foreign born; M Male

processes to the original informed consent). In case 2, the CPSO conducted several investigations and delivered a lengthy and very thorough report examining each of the numerous complaints the patient had filed against the CPP director and members of the clinical staff. The CPSO committee concluded that each one of the patient's complaints was unfounded and lacked merit. In the third case, the complaint was considered so obviously frivolous that the CPSO investigator proposed closure of the case within a two-month period. Details are shown in Table 4.

\section{Complaints through rateMDs.com}

A review of rateMDs.com revealed six entries recorded in 2007 and one in 2008 during the nine-year period of the present study. All entries were related to the CPP director, with no entries against the other two members of the medical staff. Three entries rated the CPP director very positively. The remaining four recorded complaints related to the diagnosis furnished and/or recommendations (particularly pertaining to psychological factors in the presentation, inappropriate use of medications and/or disability issues). The complainant's sex could be ascertained in only one case because the complainant stated she was the wife of a patient.

\section{Country of birth of complainants}

The overwhelming majority of complainants (over 90\%) were Canadian born - 12 of 13 PR complainants whose files were qualitatively analyzed (Table 2), three of three CPP complainants (Table 3), and one of three complainants to the CPSO (Table 4), with one additional patient immigrating to Canada at four years of age who, for all practical purposes, was raised within the Canadian system.

\section{DISCUSSION}

The present study, to our knowledge, is the first study to provide an overview of the nature of complaints and complainants from all sources against a Canadian tertiary care pain clinic. In summary, based on our results, it seems that although the prevalence of complaints launched with PR against our program is very low, there are other sources of complaints, as mentioned in the Results section. A complainant in our pain program is likely to be a Canadian-born woman; the complaints are directed against certain persons of the medical and administrative staff; and when targeting the medical staff, the complaints are based on specific issues of disagreement such as those relating to opioid administration and the consultant's opinion that psychological factors were augmenting disability or other aspects of presentation. The sources of complaints were variable because the focus differed (eg, some complaints were against both the medical and administrative staff, while others targeted only the medical staff).

\section{Prevalence of complaints}

With regard to the prevalence of complaints, Ooi (3) conducted a 10-year retrospective analysis of all complaints received at the emergency department of a hospital in Singapore. The complaint frequency was 0.26 per 1000 visits, ranging from zero to 0.44 per 1000 visits per year. The majority of the complaints $(71 \%)$ were due to medical and patientdoctor relationship problems. Of note, $33.7 \%$ of the complaints were considered valid, $21.6 \%$ not valid, and in $44.7 \%$, validity could not be determined. Furthermore, $48.4 \%$ of complaints were considered remediable. Lim et al (4) conducted a two-year retrospective chart review of a primary care service and found a very low prevalence of complaints (four per 
100,000 visits), with $38 \%$ of the complaints found to be nonjustifiable and related to unmet patient expectations and misperceptions of poor staff attitude or conduct, information and professionalism. On the other hand, Taylor et al (5) reported complaint frequency ranging between 0.5 and 45.2 per 1000 patients, depending on the departments, over a four-year period at the Royal Melbourne Hospital (Victoria, Australia).

While the number of complaints in the present study registered with PR seems small for our program over a nine-year period ( 1.73 complaints per 1000 visits), as well as for all other Krembil Neuroscience Centre programs, there are several other sources of complaints launched against the physicians and administrative staff beyond the PR department (both formal and informal) that increase the prevalence. While such complaints in the literature are divided into categories (care, attitude, communication, adverse effects, billing, etc), this depends on the system of classification an institution uses. Unfortunately, PR did not provide us with details regarding their system of classification. In our study, due to the small number of PR complaints, our qualitative analysis was more detailed to allow for understanding of the exact nature and substance of complaints. Of note, most complaints included more than one issue.

\section{Classification and substance of complaints}

Complaints launched against our program through PR, as well as those registered directly with the staff or CPP director, were slightly more frequent against the medical than the administrative staff. In the literature review, complaints are classified by a number of themes based on the institution, and are often or primarily directed against the medical staff (with physicianpatient communication issues playing a prominent role). Pichert et al (13) analyzed 6419 patient complaint reports over a seven-year period that were registered with the office of patient affairs in a large teaching hospital in Nashville, Tennessee, USA. They found one to three complaints per report to be associated with negative perception of care, communication, billings, humaneness of staff, access, and cleanliness and safety. The greatest number of complaints, however, were associated with physicians. Communication issues and physicians' attitudes play a pivotal role in complaints. Physician scores on a national skills examination in Ontario and Quebec, with regard to physician-patient communication and clinical decision making, predicted complaints later made to medical regulatory authorities (14). Nevertheless, the qualitative analysis of our data in our specific chronic pain population points to several issues between patients and physicians other than communication. Our data, therefore, are not directly comparable with the data existing in the literature from large PR series.

While the reviewed literature $(3,4)$ indicates that more than one of three complaints lack merit, in our case, the qualitative analysis showed seven of 13 complaints (54\%) to be unfounded (Table 2). The higher number of unfounded complaints may be explained by the specific nature of the chronic noncancer pain patients, who were known to have significant psychosocial issues and complex diagnoses (10-12).

\section{Profile and attributes of complainants}

There is no detailed study of the profile and attributes of complainants to a pain service. The closest description of such a profile can be obtained indirectly from a large study that focused on the characteristics of potential litigants in the United States. Fishbain et al (15) found that lawsuit causes include specific attributes of injury (negligence or none), provider (physician) attributes, physician-patient relationship and patient attributes. There was poor correlation between lawsuits and negligence. In investigating patient attributes to a specific question ('thinking about suing the doctor'), the highest percentage of affirmative responses (ie, patients thinking of suing their physicians) came from pain patients with workers' compensation claims and personal injury litigations (11.5\% versus $1.9 \%$ in the general community sample). This response was associated with specific patient attributes such as anger, mistrust, focus on compensation, addiction and substance abuse, childhood physical abuse, and higher education level (attended college). While 'thinking' is not equivalent to actual suing, our clinical experience with regard to pain complainants tends to agree with most attributes reported by the Fishbain et al study (15).

\section{Complainant sex and country of birth}

We have previously reported that the female to male ratio in our program is $1.3: 1$ (16) and that $58.6 \%$ of all new referrals are Canadian born (17). The PR data in our study surprisingly indicated a very high prevalence of female complainants (female to male ratio 3.6:1). Clearly, the prevalence of female complainants is much higher than that predicted by the female to male ratio of patients attending our program. The literature supports this finding because there are reports that, in general, women are more likely to complain against health care providers. Taylor et al (5) analyzed all complaints recorded over a four-year period at the Royal Melbourne Hospital. A statistically significant number of complaints were lodged by female patients who were Australian born.

Additional support for the general preponderance of female complainants is provided by CPSO data. A review of public complaints against physicians recorded with the CPSO disclosed 2168 complaints in 2005 and 2364 complaints in 2006, with women accounting for $60 \%$ and $63 \%$ of the complaints, respectively - data that confirm the preponderance of female complainants (data provided through written personal communication with S McCulloch, CPSO, September 8, 2008). Two separate surveys conducted by the CPSO looked into a multiplicity of factors relating to the complaints. The most salient points in the CPSO surveys were that complainants were women, usually in their 40s, who launched complaints with regard to care for their children, themselves (diagnosis, gynecological issues, etc) and their frail or ill parents. They usually had secondary school or university education (the CPSO does not collect data with regard to ethnic identifiers). For the group of female and male complainants in their late 70s and 80 s, complaints related primarily to the care provided for a failing spouse. Female complainants showed less interest in resolving complaints than male complainants. Altogether, $75 \%$ of all complaints resulted in 'no action'.

The prevalence of Canadian-born complainants in the present study (more than 90\%) is also startlingly high and quite different from the Canadian- to foreign-born patient ratio recorded in patients attending our program, in which only 58.6\% are Canadian born (17), as reported previously. These findings also seem to be supported by published literature. Bismark et al (18) studied the prevalence of complaints in a 
New Zealand hospital in relation to adverse effects. They found disparities in access and use of the complaint process in certain socioculturally deprived groups (elderly, patients of lower socioeconomic status or patients of Pacific ethnicity). Similarly, Carroll et al (19), in the United States, reported a much greater number of complaints launched by Caucasian families against a pediatric service than by African-American families. In summary, certain groups, including immigrants or those of certain ethnocultural backgrounds, are underrepresented within the complaint process. Taylor et al (5) in Australia also reported a statistically significant number of complaints lodged by female and Australian-born patients.

While the preponderance of Canadian-born complainants may be attributed to better education, and understanding or use of the system and perception of 'patient rights', there are other factors that must be taken into account, such as culturally mediated avoidance of complaining against a perceived authority, lower expectations of foreign-born patients resulting in less dissatisfaction, issues of entitlement more entrenched in Canadian-born patients (with complainants often viewing their 'disability status' as being threatened by the doctors' diagnosis), the negative perception of Canadian-born patients with regard to the contribution of psychological factors to disability, and disagreement with the physicians with regard to opioid administration. Of note, excessive or inappropriate opioid administration is almost an exclusively Canadian-born patient phenomenon in our own CPP population; only $1.6 \%$ of high opioid users in a study of 184 injured workers in our clinic were foreign born (20).

With regard to our pain population in general, we have previously reported that female chronic pain patients attending our clinic are more likely to have psychological factors contributing to their disability $(16,17)$. Additionally, female sex is considered by others to be a risk factor for chronic pain disorders (21). Based on the detailed analysis of complaints in our study, the overwhelming majority of complaints against the medical staff pertained to recognition by the staff of psychological factors and inappropriate use of opioids. The complainants may have considered the medical reports to be threatening to the validity of their complaints, the status of their disability or their opioid intake. Furthermore, as per our own studies $(16,17)$, it is likely that female patients who complained have a higher prevalence of psychiatric or psychological factors in our sample.

\section{Defensive strategies instituted by staff}

The impact of complaints on staff has not been studied extensively. Jain and Ogden (22) surveyed general practitioners against whom patients had launched a complaint. The authors found that the complaints generated different reactions (ie, defensive practice, planning to leave general practice, becoming immune to complaints or considering it to be a learning experience). In particular, when the complaints were launched formally to the physicians' regulatory body, physicians reported short- and long-term changes in their practice, and instituted defensive medicine by withdrawing from the provision of certain services and avoiding perceived at-risk activities (23). Given the fact that tertiary care pain clinics see many complex pain patients with difficult pain problems, high levels of psychiatric comorbidity and compensable issues, it is conceivable that such patients with higher levels of anger, addiction, etc, issues (15) are more prone to complaining. While the CPP has operated for 27 years, over the past two years, the CPP staff has instituted defensive practices because they believed that such complaints were taking an emotional toll on them. The changes in our practice (other than instituting a 'triple' process of consent as stated earlier, based on one CPSO complaint) came about as a result of medical and administrative staff meetings and discussions. These changes include the following:

1. Our telephone system was converted to a standardized voice mail system over the past 1.5 years, to reduce the administrative staff's personal contact with patients. We have observed that frontliners, such as secretaries and clerks, bear the brunt of verbal complaints by the patients. In our experience, the majority of complaints are addressed to female but not male administrative staff, and also seem to be related to personalities both of the complainants and the female administrative staff.

2. Verbally abusive, excessively demanding or noncompliant patients, in the opinion of the consultants, are not offered admission to our inpatient service (all admissions are elective).

3. Our opioid prescribing policies have become stricter because prescription of opioids seems to be a contentious issue and a reason for complaints. Patients addicted to opioids are only offered consultation; advice is sent to the referring practitioner, or the patient is referred to a facility dealing with chemical dependence if needed. In the past, the CPP physicians became primary opioid prescribers for some patients due to extenuating circumstances (eg, loss of a patient's family practitioner; the CPP physician continued to prescribe opioids until a new physician was found). However, as of January 2009, the CPP physicians have altered their opioid prescribing policy and are willing to prescribe opioids when they initiate them, or in case a patient's management needs optimization, but only if the referring physician is willing to assume patient and prescription responsibility after the patient is stabilized. However, the referring physicians are assured in writing that our staff is willing to provide ongoing consultation at regular six- to 12-month reviews or earlier if the need arises. This change in opioid prescribing policy was approved by the institution's medical advisory committee and communicated to all departments via the medical staff bulletin (volume 38, issue 3, 2009) because it follows similar principles established in other academic pain clinics.

While our data may not be generalizable to other clinics, departments or institutions, they are the first Canadian pain clinic data we know of that addresses the issues and nature of complaints and complainants. Admittedly, there are many issues related to patient satisfaction that are poorly understood. In the era of 'patient-centred care', well-designed studies looking at patient complaints, staff attitudes, effect of complaints on staff, etc, will assist the delivery of care to patients and their families, as well as devise ways to assist and educate the staff exposed to such complaints. Future studies should also examine the variety of attributes (such as the presence of compensation or litigation, level of education, etc) that affect both the origin and the resolution of complaints. 


\section{REFERENCES}

1. Kassim PN. Reducing medical complaints and litigation in Malaysia: Turning patients' voices into opportunities. J Law Med 2007;15:303-11.

2. Moore LG, Wasson JH. An introduction to technology for patientcentered, collaborative care. J Ambul Care Manage 2006;29:195-8.

3. Ooi SB. Emergency department complaints: A ten-year review. Singapore Med J 1997;38:102-7.

4. Lim HC, Tan CB, Goh LG, Ling SL. Why do patients complain? A primary health care study. Singapore Med J 1998;39:390-5.

5. Taylor DM, Wolfe RS, Cameron PA. Analysis of complaints lodged by patients attending Victorian hospitals, 1997-2001. Med J Aust 2004;181:31-5.

6. Gale C, Arroll B, Coverdale J. Aggressive acts by patients against general practitioners in New Zealand: One-year prevalence. N Z Med J 2006;119:U2050.

7. Doig G. Responding to formal complaints about the emergency department: Lessons from the service marketing literature. Emerg Med Australas 2004;16:353-60.

8. Krause HR, Bremerich A, Rustemeyer J. Reasons for patients' discontent and litigation. J Craniomaxillofac Surg 2001;29:181-3.

9. Halperin EC. Grievances against physicians: 11 years' experience of a medical society grievance committee. West J Med 2000;173:235-8.

10. Crook J, Tunks E, Rideout E, Browne G. Epidemiologic comparison of persistent pain sufferers in a specialty pain clinic and in the community. Arch Phys Med Rehabil 1986;67:451-5.

11. Crook J, Weir R, Tunks E. An epidemiological follow-up survey of persistent pain sufferers in a group family practice and specialty pain clinic. Pain 1989;36:49-61.

12. Von Korff M, Lin EH, Fenton JJ, Saunders K. Frequency and priority of pain patients' health care use. Clin J Pain 2007;23:400-8.

13. Pichert JW, Federspiel CF, Hickson GB, et al. Identifying medical center units with disproportionate shares of patient complaints. Jt Comm J Qual Improv 1999;25:288-99.
14. Tamblyn R, Abrahamowicz M, Dauphinee D, et al. Physician scores on a national clinical skills examination as predictors of complaints to medical regulatory authorities. JAMA 2007;298:993-1001.

15. Fishbain DA, Bruns D, Disorbio JM, Lewis JE. What patient attributes are associated with thoughts of suing a physician? Arch Phys Med Rehabil 2007;88:589-96.

16. Mailis-Gagnon A, Yegneswaran B, Lakha SF, et al. Pain characteristics and demographics of patients attending a university-affiliated pain clinic in Toronto, Ontario. Pain Res Manage 2007;12:93-9.

17. Mailis-Gagnon A, Yegneswaran B, Nicholson K, et al. Ethnocultural and sex characteristics of patients attending a tertiary care pain clinic in Toronto, Ontario. Pain Res Manage 2007;12:100-6.

18. Bismark MM, Brennan TA, Paterson RJ, Davis PB, Studdert DM. Relationship between complaints and quality of care in New Zealand: A descriptive analysis of complainants and noncomplainants following adverse events. Qual Saf Health Care 2006;15:17-22.

19. Carroll KN, Cooper WO, Blackford JU, Hickson GB. Characteristics of families that complain following pediatric emergency visits. Ambul Pediatr 2005;5:326-31.

20. Arvantaj A, Mitrovich B, Lakha SF, Mailis N, Mailis-Gagnon A. Characteristics of injured chronic pain workers identified by Workers Safety and Insurance Board (WSIB) staff as management problems. Pain Res Manage 2008;13:131. (Abst)

21. Tyrer SP, Capon M, Peterson DM, Charlton JE, Thompson JW. The detection of psychiatric illness and psychological handicaps in a British pain clinic population. Pain 1989;36:63-74.

22. Jain A, Ogden J. General practitioners' experiences of patients' complaints: Qualitative study. BMJ 1999;318:1596-9.

23. Cunningham W, Dovey S. The effect on medical practice of disciplinary complaints: Potentially negative for patient care. N Z Med J 2000;113:464-7. 


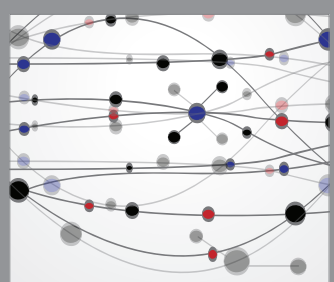

The Scientific World Journal
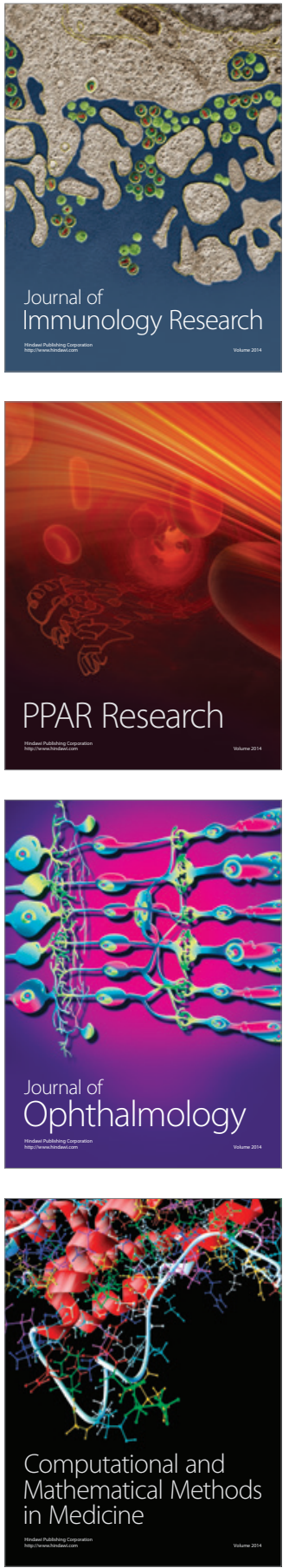

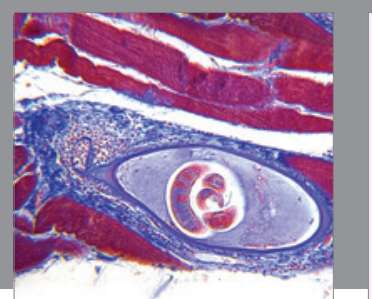

Gastroenterology Research and Practice

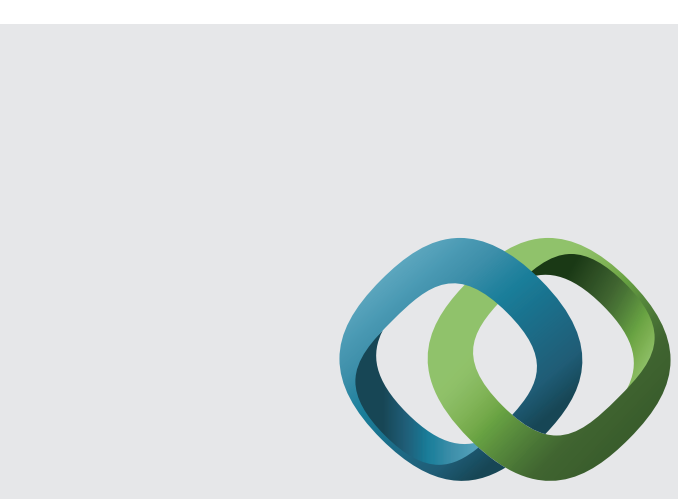

\section{Hindawi}

Submit your manuscripts at

http://www.hindawi.com
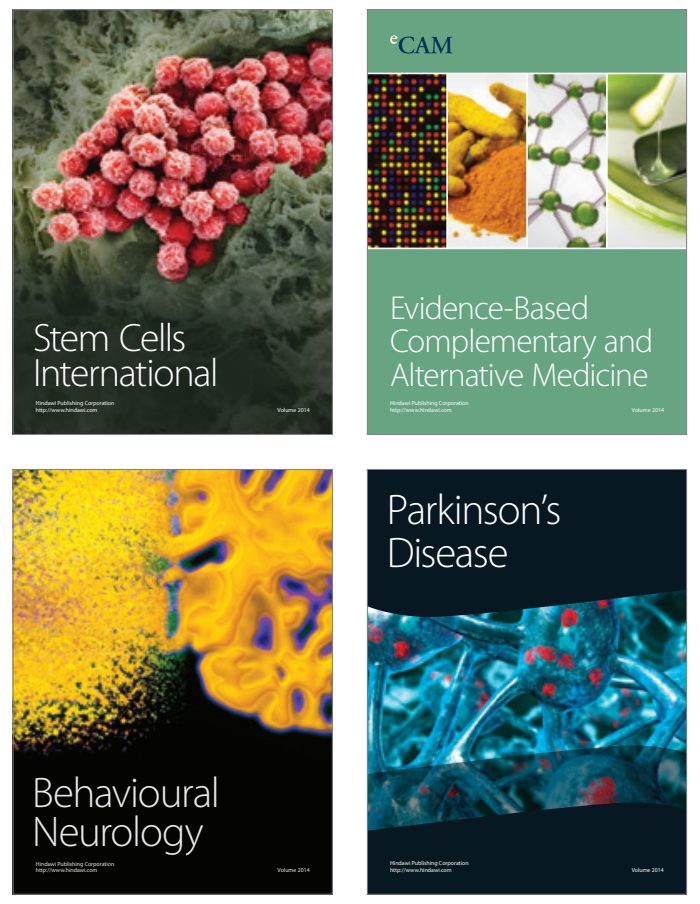
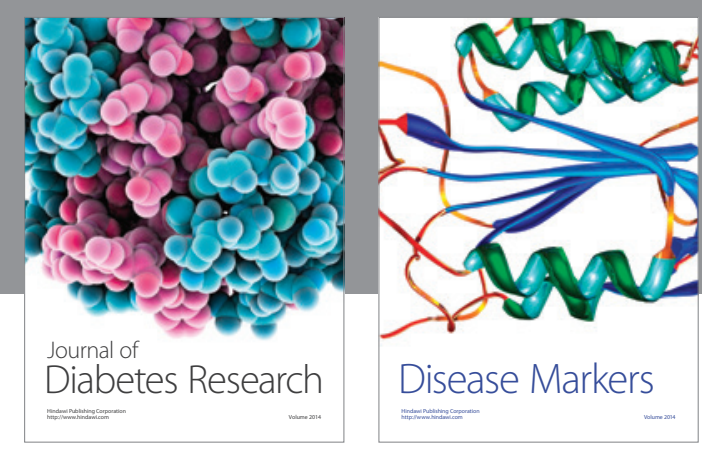

Disease Markers
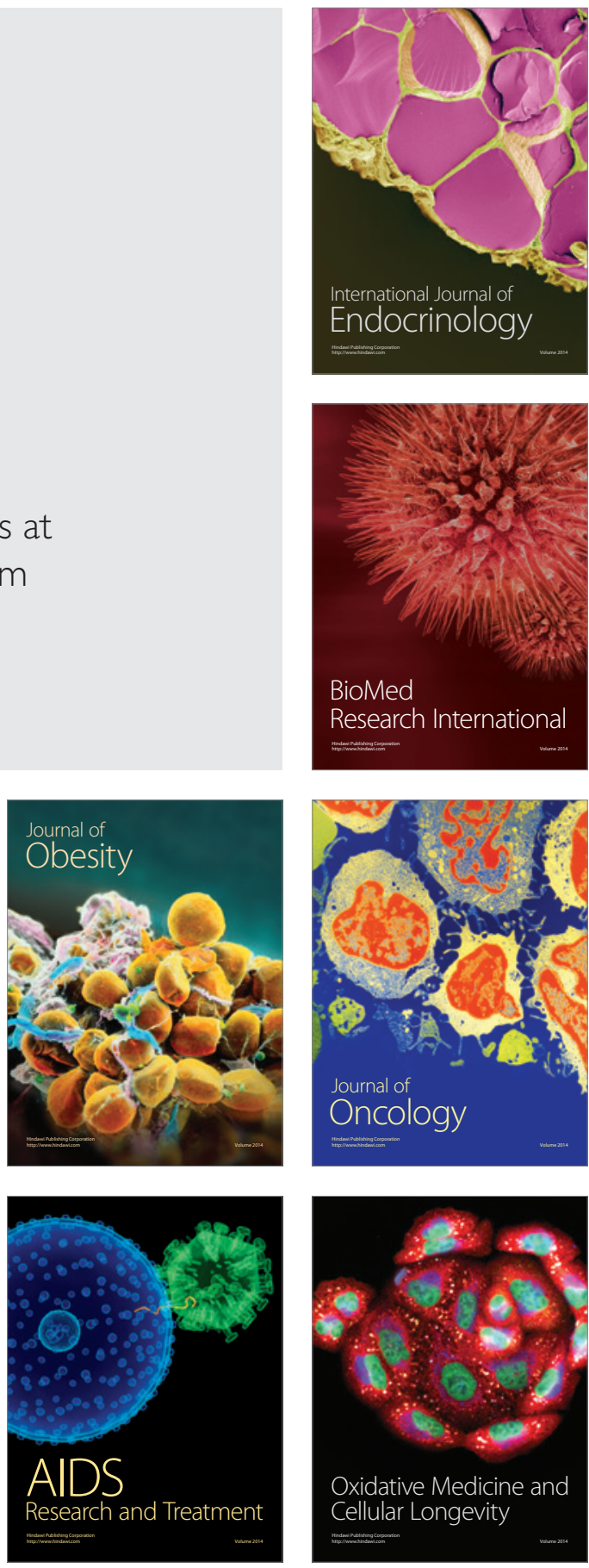